\title{
"Você é o que Google diz que você é": a vida editável, entre controle e espetáculo
}

\section{Paula Sibilia}

Doutora; Universidade Federal Fluminense; Rio de Janeiro, RJ, Brasil paulasibilia@gmail.com

\begin{abstract}
Resumo
Este artigo retoma o debate acerca do "direito ao esquecimento" que alguns usuários da internet solicitam a buscadores como Google e Yahoo. O que se pede, nesses casos, é que sejam apagados certos dados pessoais referidos a situações do passado que, embora sejam verdadeiros, o demandante considera que prejudicam a sua reputação. As discussões em torno deste assunto parecem sugerir que estão se consumando algumas transformações importantes nos modos como nos relacionamos com as lembranças próprias e alheias, abrindo o horizonte (moral e legal) para uma "memória editável", cujo critério de veracidade reside na exposição ao olhar dos outros. Trata-se de uma reflexão ensaística que propõe uma perspectiva genealógica sobre o fenômeno, em diálogo com autores fundamentais dos séculos XIX e XX, tais como Benjamin, Bergson, Borges, Debord, Deleuze, Foucault, Freud e Nietzsche.
\end{abstract}

\section{Palavras-chave}

Memória. Esquecimento. Internet. Subjetividade. Visibilidade.

\section{Introdução}

O que faz com que cada sujeito seja quem é e que os outros o identifiquem como tal? A capacidade de lembrar da própria experiência compõe, sem dúvida, uma parte importante dessa definição, pois esse acúmulo de recordações é a base a partir da qual se gera um relato a respeito da própria vida e do seu protagonista: eu. Ou seja, essa complexa entidade que, sem pensar demais, costumamos nomear recorrendo à primeira pessoa do singular. 0 fato de que os outros também tenham acesso às narrativas tecidas em torno dessa memória - de modos obviamente fragmentados e formando um caleidoscópico de apropriações - é outro elemento importante, pois esse conhecimento partilhado da história vital de alguém contribui para assentar a "identidade" de cada um. Contudo, a maneira como isso se efetua, 
tanto no plano individual como no coletivo, talvez seja uma das tantas características de nossos "modos de ser" que estão mudando, em sintonia com os avanços das tecnologias digitais de comunicação e informação, acompanhando o ritmo das intensas transformações socioculturais, políticas e econômicas que gestaram esses movimentos.

"Antes da internet, se você era uma má pessoa, podia começar uma nova vida [...].", ponderou numa entrevista o advogado argentino Miguel Sumer Elías, especialista em direito informático (GIANBARTOLOMEI, 2012, doc. não paginado, tradução nossa). Como costumava se dizer em outros tempos, esse indivíduo podia tentar "se regenerar". De que modo? Elaborando as próprias experiências passadas para iniciar uma nova etapa, por exemplo, contando com certo esforço e algo de sorte, além da benéfica ajuda dos imprescindíveis aliados, fossem estes voluntários ou não. Mas isso deixou de ser factível porque agora "você é o que Google diz que você é", conforme concluiu, em seus depoimentos, o advogado acima citado (GIANBARTOLOMEI, 2012).

A fonte da verdade a respeito de quem é - e quanto vale - cada sujeito parece ter se deslocado. Esse saber já não brota mais das próprias entranhas, onde se acreditava que ficavam hospedadas as lembranças das vivências, bem como os pensamentos, as emoções, os princípios éticos e os sentimentos de cada um, de acordo com a perspectiva moderna de uma interioridade laica assimilável a conceitos como os de psiquismo ou mente. Agora, essa instância capaz de atestar quem é cada um parece ser outra; e, de fato, é bem diferente: a rede mundial de computadores. Nada menos que a internet, essa sorte de Aleph do novo milênio (BORGES, 1999a), que congrega todos os olhares alheios e que expõe escancaradamente a totalidade do que existe, ora encarnado no emblemático buscador da empresa Google.

\section{Direito a esquecer(-se) e a ser esquecido}

O homem é o único animal capaz de lembrar. Pelo menos é isso o que supomos, e também é o que Friedrich Nietzsche observou em sua Segunda consideração intempestiva, datada em 1873, com um significativo subtítulo: Da utilidade e desvantagem da história para a vida. Mas esse raro privilégio da memória não era, para o filósofo alemão, uma grande qualidade capaz de enaltecer o gênero humano; aliás, poder-se-ia dizer todo o contrário. "É possível viver quase sem lembranças, sim, e viver feliz assim, como o mostra o animal [...]", constatava então Nietzsche, “[...] mas é absolutamente impossível viver, em geral, sem 
esquecimento.". Por isso, a muito humana possibilidade de esquecer - ruminando ou mastigando o vivido - seria, para ele, "a capacidade mais elevada do espírito." (NIETZSCHE, 2003, p. 9-10). Hoje pode parecer estranha essa afirmação, lançada numa época em que o orgulhoso ideal de progresso ocidental ainda estava no ápice como a grande meta de um Ocidente triunfante. Entretanto, esse autor não foi o único a se revoltar contra as tiranias da memória em plena modernização do mundo, defendendo em seu lugar as potências libertadoras do esquecimento.

Para se ter uma ideia mais cabal das desventuras que lembrar-se de tudo pode implicar, basta evocar o célebre protagonista do conto de Jorge Luis Borges, Funes o memorioso, publicado originalmente em 1942. Esse personagem fictício não podia se esquecer de nada e, de acordo com a sagaz interpretação borgiana, uma tal quantidade avassaladora de lembranças o impedia de viver (BORGES, 1999b). Não se trata de uma metáfora: a impossibilidade era literal, não só literária ou lírica. Para poder agir no mundo é necessário relegar tudo aquilo que, no momento presente, só poderia atrapalhar a vital percepção com o pesado fardo de inúmeras lembranças. Isso é algo que também seria elucidado - não sem poesia - pelo filósofo Henri Bergson (1999), nas páginas de seu livro Matéria e memória, audazmente subtitulado Ensaio sobre a relação do corpo com o espírito. Suas reflexões delatam que esse autor francês - honrado com o Prêmio Nobel de Literatura, em 1927, devido em grande medida ao singular sucesso dessa obra - também se deixou interpelar pelas complexidades que implicava habitar os derradeiros anos do século XIX e os primeiros do XX; assumindo, em particular, a aloucada aventura de ter que explicar de maneira racional em que consiste a condição humana.

Tudo isto vem à tona, agora, porque subitamente convivemos com uma máquina monstruosa que - assim como o desventurado Irineo Funes do conto de Borges (1999b) parece se lembrar de tudo, inclusive daquilo que poderia (ou supõe-se que deveria) ser esquecido. Trata-se, é claro, da internet. A esse fabuloso atributo da rede mundial de computadores - a capacidade de nada esquecer - apontam as reclamações que vêm se erguendo, nos últimos anos, contra os motores de busca ou search engines, tais como Google ou Yahoo, em nome do "direito ao esquecimento" daqueles que se sentem lesados por essa memória demasiadamente incisiva. 0 que se pede, nesses casos, é que sejam apagados certos dados pessoais que se referem a situações do passado e que, embora sejam verdadeiros, o demandante considera que o prejudicam de algum modo. Sobretudo, pela sua ingrata capacidade de manchar algo indispensável num mundo governado pela lógica 
empresarial e submetido aos impiedosos vaivéns de todos os mercados: a reputação pessoal. Em tempos de excessiva exposição, em suma, ser esquecido - ou bem mais precisamente, que algum detalhe infeliz a nosso respeito fique protegido por um abençoado manto de escuridão - pode ser um luxo difícil de alcançar. A batalha rumo à sua conversão em "direito", portanto, apela à força da lei para atingir essa conquista que, talvez, seja quimérica.

Em maio de 2014, a União Europeia tomou uma decisão insólita nesse sentido, que provocou uma imensa onda de debates ao repercutir nos noticiários de todo o planeta. Segundo as medidas aprovadas naquele momento, os buscadores da internet deveriam atender às petições dos usuários quando estes solicitassem que fossem eliminados de seus resultados alguns conteúdos que os afetavam de forma negativa. A partir dessa polêmica resolução, e por toda parte, não cessaram de proliferar os processos judiciais com vistas a limitar a informação disponível acerca de um determinado indivíduo, bastando este considerar que tal lembrança pública o danifica.

Assim, por exemplo, entre os casos que mais ecoaram, estão os de atrizes ou modelos que pedem a omissão de links para sites pornográficos em todas as buscas associadas a seus nomes. Nessa classe de pleitos, é evidente que a demandante não quer ser completamente esquecida, pois ela vive de sua fama como "celebridade"; no entanto, reclama que seja apagado algum episódio específico do seu passado que - pelo menos em sua opinião, e isso é o único que importa - a condena. Mas não se trata apenas desse tipo de litígios. A variedade é enorme: há aqueles que desejam desaparecer dos resultados mostrados por Google, pois temem pela sua segurança, por exemplo, ou porque almejam proteger a sua privacidade. Ou, de um modo geral, como nos casos antes mencionados, porque os associam a acontecimentos de suas vidas que prefeririam não fossem lembrados por ninguém. Por exemplo? Um conflito judicial ou um dado financeiro, ou então uma fofoca ou qualquer referência mais ou menos vergonhosa a respeito dos diversos aspectos de suas experiências vitais.

São inúmeros os ingredientes deste debate, que é muito complexo e não só está cheio de ambiguidades, mas também traz à tona algumas contradições interessantes. Em primeiro lugar, cabe frisar que não se trata do tradicional "direito à réplica" que a imprensa concede àqueles que se consideram ofendidos por uma notícia publicada de modo incorreto, com informações falsas ou inexatas. Associada aos valores democráticos e à liberdade de expressão, essa normativa está em pauta desde a França revolucionária de 1789 e, com a 
generalização desse espírito, tem sido plasmada nas constituições nacionais e nos códigos legais de cada país. Mas aqui o problema é outro: os fatos revelados pela internet são verdadeiros, nestes casos ninguém nega ou contesta essa veracidade. 0 que se consente agora é uma novidade: o desejo do protagonista no sentido de que esses dados reais permaneçam ocultos.

Por isso, este reconhecimento tão recente do "direito ao esquecimento" por lei parece capaz de abalar não apenas um conjunto de velhos costumes e certezas, mas também alguns alicerces de nossa tradição filosófica. Surge, por exemplo, a seguinte dúvida: por ventura estaria se realizando, afinal, em pleno século XXI, aquele feliz desprendimento das garras da memória proposto pelos autores anteriormente mencionados - Nietzsche (2003), Bergson (1999) e Borges (1999a, 1999b) - que, não por acaso, marcaram a fogo o pensamento e o imaginário dos séculos XIX e XX? Talvez sim, em certo sentido, porém não exatamente como eles o enunciaram. Porque o que entendemos por memória e esquecimento, inclusive o que consideramos que significa "ser alguém", e a relação que isso mantém com as próprias lembranças, são todas definições que costumam mudar nos diversos contextos socioculturais. Com as sacudidas mais recentes da nossa história, talvez tenham se reconfigurado de maneira inesperada e ainda impensada.

Continuando nessa perspectiva, não surpreende muito que figuras como Friedrich Nietzsche e Jorge Luis Borges tenham se encarniçado contra os possíveis abusos da memória, já que suas obras costumavam disparar agudos dardos em direção aos valores vigentes na época em que cada um deles escreveu, ironizando e colocando em xeque algumas das crenças mais prezadas da cultura ocidental em seus respectivos momentos. E, como é sabido, tanto o século XIX como boa parte do XX estiveram obcecados pela memória. Ou seja, pela suposta verdade que devia emanar dos arquivos e dos registros preservados naquele período com minuciosa laboriosidade, tanto nas mais respeitáveis instituições estatais como na sagrada intimidade de cada lar. Com a valiosa ajuda desses acervos verídicos - dos prontuários policiais ou as coleções museológicas até os diários íntimos e os álbuns familiares - operava-se a reconstrução histórica de todos os fatos com reverente fidelidade ao que realmente aconteceu.

Até o mesmíssimo Sigmund Freud (1978), autor de uma das teorias mais bemsucedidas sobre o que significa ser humano na era moderna, atribuiu à memória um papel despótico. De acordo com esse saber tão sedimentado entre nós, podemos não lembrar algo ou acreditar que o esquecemos, mas tudo o que vivemos nos constitui de um modo profundo 
e crucial. As experiências passadas alimentam o que somos porque definem as forças - bem como as dificuldades e impotências - que nos habitam, dando lugar a uma cosmovisão na qual resulta impensável essa lógica do apagamento voluntário que hoje se insinua. Mesmo se um determinado episódio não se encontra esclarecido no nível mais imediato da consciência, segundo essa perspectiva cultural que tem sido tão impregnada pela psicanálise, admite-se que todo o vivido está abrigado em substratos ainda mais profundos de nossa configuração psíquica. E não há o que fazer: ainda que pensemos que não nos lembramos de algo, ainda que tentemos soterrar uma determinada recordação, ainda que briguemos resistindo contra tudo isso, mesmo que o neguemos obstinadamente e queiramos extirpá-lo de nossas vidas, estamos feitos dessa matéria tão escorregadia como insistente. Nada menos que a memória do que alguma vez fomos e que fatalmente nos constitui.

\section{Deletar lembranças para editar o passado}

O quadro pintado no parágrafo anterior não soa completamente alheio às convicções que vigoram na atualidade; contudo, é preciso admitir que muita água correu sob a ponte desde aquelas vitorianas épocas. E, por isso, é provável que a nossa relação com a memória já não seja a mesma. Cartografar essas mutações não é uma tarefa simples, visto que os indícios são múltiplos e estão cheios de ciladas. Hoje, por exemplo, talvez mais do que nunca, são realizados incontáveis eventos e são inaugurados museus ou parques temáticos para prestar culto a uma imensa diversidade de acontecimentos do passado. Isso, sem deixar de lado a encenação espetacularizada de épocas inteiras, quando uma infinidade de material jornalístico ou bibliográfico, bem como cinematográfico e televisivo, também se ocupa do assunto. E o mercado aproveita para reciclar tudo, enquanto fatura com as modas em clima retrô ou vintage. Nessa mesma direção, é impossível não pensar na multidão de blogs que proliferam na internet, assim como nos perfis das redes sociais e nas toneladas de fotos que geramos para documentar cada instante de nossas peripécias vitais - ou de seja lá o que for - multiplicando ao paroxismo os registros e os arquivos.

De modo que aquela mania oitocentista de tudo registrar e arquivar parece ainda muito presente em nossa cultura do século XXI, inclusive até exacerbada. Mas o curioso é que isso convive com uma novidade, sobre a qual vale a pena colocar a ênfase: as ferramentas para apagar lembranças e, junto com elas, a legitimidade de fazê-lo. Algo que no 
auge da era moderna teria sido inconcebível - ou, no mínimo, condenável - para a enorme maioria dos mortais. Nesse sentido, a reivindicação do "direito ao esquecimento" que estourou há pouco tempo nos debates públicos não parece ser um fato isolado, mas algo alinhado com essa tendência mais geral que, talvez, esteja assinalando importantes transformações em nossos valores e crenças, bem como nos modos em que construímos as nossas subjetividades.

Já faz alguns anos que estão se desenvolvendo diversos experimentos científicos com vistas a descobrir uma substância química que seja capaz de eliminar reminiscências dolorosas dos cérebros daqueles que sofrem de "estresse pós-traumático", por exemplo (SIBILIA, 2016). É a esse esforço que alude, de modo ficcional, o filme Brilho eterno de uma mente sem lembranças, dirigido por Michel Gondry e estreado em 2004. Os personagens dessa história recorrem a uma empresa que vende esse tipo de serviços para extirpar, de modo indolor e com alta praticidade, a tristeza de uma desilusão amorosa (BRILHO..., 2004). Fica claro que essa tecnologia ainda não está disponível, embora seja pensável e até chegue a ser desejável ou pelo menos desejada, motivo pelo qual já há várias pesquisas em neurociências e farmacologia que avançam nesse caminho com total seriedade.

Não é casual que, justamente agora, surjam esses sonhos de uma memória editável ao gosto do consumidor, como se a própria vida fosse uma história contada em suporte digital, cujos episódios desagradáveis pudessem ser apagados - ou melhor, deletados - com a eficácia típica dos computadores e por livre decisão de cada um. Ao que parece, trata-se de mais um caso em que a metáfora acaba se aderindo ao referente, de modo que já não é mais possível desgrudar ou diferenciar um elemento do outro. A Timeline de Facebook, por exemplo, que ainda é a mais popular rede social da internet, não representa apenas a epopeia do seu protagonista por meio de uma série de imagens cuidadosamente selecionadas, mas de algum modo a apresenta, a performa e a constitui. Agora, ambos os planos - vida e relato audiovisual - se fundem e se confundem nessa biografia cuja textura é informática.

Tratadas como arquivos digitais, as lembranças deixam de ser concebidas como aquelas entidades etéreas e misteriosas que, de acordo com as crenças modernas, nutriam a interioridade de cada indivíduo. Considerava-se que essa essência oculta e enigmática era algo decididamente analógico; em termos contemporâneos - e, portanto, anacrônicos diríamos que a sua materialidade era incompatível com qualquer dispositivo eletrônico que procurasse escaneá-la para digitalizar seus “conteúdos”. Justamente por isso, jamais poderia 
se converter em informação. Devido a essas peculiaridades, exigia outras técnicas para o seu deciframento ou a sua interpretação. As viagens introspectivas e as evocações retrospectivas, por exemplo, faziam parte desses rituais cotidianos cuja meta era conhecer a si mesmo e dar um sentido coerente ao caótico fluxo que compõe toda e qualquer vida. Não é por acaso que várias ferramentas tipicamente oitocentistas se destinavam a tal fim: desde o diário íntimo até a psicanálise, passando pela leitura de romances e pelas trocas epistolares.

Contudo, algo parece ter mudado bastante nesse panorama. Quando se opera segundo a lógica informática, se ninguém lembrar que algo aconteceu - inclusive consigo mesmo - porque esse dado foi eliminado tecnicamente, então, pode-se agir como se isso nunca tivesse ocorrido. É comparável ao que acontece quando se recorre ao bisturi para modelar o próprio aspecto físico, por exemplo, ou quando se pratica o ghosting bloqueando alguém de todas as redes de comunicação para finalizar assim um relacionamento sem ter que dar explicações enfadonhas. Ou, então, quando alguém edita a "linha do tempo" em sua página de Facebook, ou quando lhe exige a Google que deixe de mostrar imagens e textos vergonhosos a seu respeito. Em todos esses casos, o que somos perde a sólida consistência que costumava ostentar, para se tornar algo bem mais flexível e reprogramável ao gosto de cada um. Convém ressaltar que não se trata de uma questão meramente tecnológica: se as ferramentas para poder fazê-lo estão sendo inventadas agora, isso acontece porque neste momento histórico nos resulta legítimo não só pensá-lo, mas também eventualmente realizá-lo.

A naturalização de todas essas atitudes entre nós, portanto, sugere algo inquietante. A matéria que nos constitui parece ter mudado sutilmente para transmutar-se em outra coisa, ao se redefinirem os pilares que sustentam a história pessoal de cada sujeito. Já não é algo cujos vestígios são guardados no mais recôndito do próprio lar, como se fazia com o álbum de fotos familiares ou com as cartas e os diários da era moderna, por exemplo. Mas não se trata só disso: esses rastros do vivido tampouco se acumulam "dentro" das entranhas mais profundas de cada um, nem no empoeirado porão da memória nem no fundo do coração. Em vez disso, agora, essa substância que nos conforma parece ter se tornado uma espécie de capital que se deve administrar com o propósito prioritário de mostrá-lo. Por isso, o que importa para verificar a sua existência - ou, então, a sua irrelevância - é, precisamente, que os outros tenham acesso ou não a essas informações, para além de que seja algo de fato ocorrido e que, portanto, integre a história real de cada indivíduo. 
A transformação aqui em foco pode parecer sutil, mas está longe de ser insignificante. Em lugar de encarnar naqueles tesouros que deviam ser protegidos na intimidade do espaço privado - e/ou na própria interioridade - para dar consistência ao $e u$, agora a trajetória vital de cada sujeito se tornou um relato editado com muito cuidado porque a sua função primordial consiste em ser exibido. Isto é, procura-se que os outros o assistam como se fosse um espetáculo e que o testemunhem com seus próprios olhos; e, na medida do possível, que também o "curtam" clicando nos botões adequados ou fazendo comentários elogiosos, inclusive compartilhando-o com outros contatos para obter uma repercussão ainda mais ampla.

\section{Performar o que se é para o olhar alheio}

Embora ainda seja algo bastante recente, a constatação é inegável: já não se guarda quase nada para sempre, nem na interioridade impalpável da alma, nem na privacidade da casa. Não se conservam fotos impressas, cartas ou diários, por exemplo, pois se tornou imprescindível compartilhar logo tudo nas telas e, em seguida, descartá-lo para renovar o próprio perfil e deixar lugar às novidades. É preciso exibir tudo o que se é; ou, mais exatamente, fazer uma sorte de curadoria permanente daquilo que se está ou se deseja parecer, clamando sempre pela imprescindível aprovação alheia, pois essa será a instância capaz de conceder valor - e até mesmo estatuto de verdade - ao que se expõe. Refinando mais um pouco essa intuição, dir-se-ia que é necessário mostrar tudo o que cada um gostaria que os outros considerassem que se é, para assim receber o seu almejado apoio com o polegar para cima e outras formas do aplauso contemporâneo, pois esse gesto alheio será capaz de confirmar a própria existência ao legitimá-la.

Além disso, cabe destacar outros aspectos destas complexas transformações históricas. Em primeiro lugar, tem ficado cada vez mais ambígua a diferença que separava ambos os polos daqueles pares de oposições, antes consideradas excludentes, alguns dos quais foram mencionados no parágrafo anterior. Assim como ocorre com as categorias de público e privado, agora essência e aparência também se confundem e misturam nestas novas práticas vitais, sem privilégios morais para a primeira nem desprezos para a segunda. O importante é que se somos algo ou alguém, tudo isso tem que estar à vista; porque se não se mostra e os demais não o enxergam, então nada nem ninguém poderá nos garantir que existe ou que tem algum valor. Dessa curiosa mutação se desprende algo importantíssimo: o 
fato de que alguma coisa tenha acontecido ou não, parece ter perdido relevância. Também muda a maneira em que uma lembrança do passado afeta o presente, sem necessariamente se afixar de modo indelével na "essência interior" do seu protagonista. Em vez disso, o que mais interessa agora é outra coisa: o efeito que essa informação é capaz de produzir nos outros. 0 que determinará a sua veracidade é o modo como os demais a enxergarão e avaliarão, pois é assim que somos julgados e legitimados (ou não) pelo olhar alheio.

Daí que as reivindicações em torno ao "direito ao esquecimento" também costumam se apresentar sob outro rótulo: o "direito à autodeterminação informativa". Neste caso, o que se tenta defender é a faculdade de cada indivíduo para administrar por si mesmo a divulgação e o uso dos dados referidos à sua pessoa. Esses sonhos de autonomia também levam a marca da atualidade. Essa ilusão de controle total, porém, não cessa de nos desapontar, dando ressonâncias inesperadas às sagazes teorias de Gilles Deleuze (1992) sobre o mundo contemporâneo. Cabe lembrar que esse filósofo francês recorreu à expressão "sociedades de controle" para designar o "novo monstro", como ele mesmo ironizou em seu breve e contundente ensaio publicado em 1990. A que se referia? À gradual implantação de um regime de vida inovador, que se distanciava dos modos de funcionamento tipicamente modernos e industriais, ou seja, daquilo que Michel Foucault (1977) nomeara "sociedades disciplinares" em seus estudos publicados alguns anos antes.

Essas novidades começaram a se delinear nas últimas décadas do século passado, com o apoio crucial das tecnologias eletrônicas e digitais, para configurar uma organização social mais compatível com o ágil capitalismo "neoliberal" que se consagrou no final do século XX e no início do XXI. Isto é, um sistema regido pelo excesso de produção e pelo consumo exacerbado, pelo marketing e pela publicidade, pela flexibilidade e pela velocidade, pelos fluxos financeiros em tempo real e pela interconexão em redes globais de comunicação. E, sobretudo, um modo de vida marcado pela decadência de certos estabelecimentos básicos da sociedade moderna - tais como a escola, a fábrica, a prisão e o hospital, inclusive a casa destinada a hospedar a família nuclear inspirada no modelo burguês. De um modo paralelo, oposto, mas também complementar a esse declive, a empresa foi se entronizando como uma sorte de inspiração exemplar que impregnaria a todas as demais instituições. Inclusive, e talvez fundamentalmente, às versões mais atuais daqueles fósseis modernos. Ao contagiá-las com seu onipresente "espírito empresarial", reformula fatalmente todas essas instituições, numa crescente compatibilização com os ritmos e as demandas da contemporaneidade. 
Como parte desse movimento, entraram em crise as figuras de autoridade mais tradicionais: pais, maridos, chefes, mestres, diretores, lei, Estado. Assim, também desabou o antigo sistema de poder centralizador, que exercia uma vigilância vertical e internalizada por meio de regulamentos e culpas. Entretanto, por mais intensas e vertiginosas que tenham sido essas transformações, a sua colocação em prática não significou uma libertação total das velhas amarras; ou, pelo menos, não foi apenas isso o que aconteceu. Junto com esse afrouxamento das opressões mais antiquadas, abriu-se o horizonte para a implantação de um tipo de controle descentralizado, embora bem mais sutil e eficaz, que opera em todo momento e lugar, além de se exercer em todas as direções e em fluxo constante, graças à espantosa ubiquidade dos dispositivos digitais de comunicação e informação. Essa eficácia se deve, em boa medida, ao fato de que o uso desses dispositivos é voluntário e não obrigatório ou prescrito por lei, embora seja estimulado pelo mercado e pela mídia, em sintonia com as poderosas promessas de felicidade que hoje nos enfeitiçam. Além de se tratar de consumos em seu sentido mais estrito; afinal, ninguém desconhece que são produtos e serviços nada gratuitos, e que devem (ou deveriam) ser renovados constantemente. Em síntese, trata-se de um poder extremamente ágil e com uma eficiência inédita, distribuído pela totalidade do tecido social, como Deleuze (1992) vislumbrara com tanta perspicácia, já faz mais de um quarto de século.

Contudo, suspeita-se que esse controle sobre a fatal insegurança da vida opere mais como uma armadilha muito lucrativa que como um fato consumado, ou mesmo como algo que alguma vez possa vir a se consumar. 0 mercado, a tecnociência e os meios de comunicação selam, todos os dias, uma aliança tácita para manter essa dinâmica em funcionamento. Esse movimento se vê atiçado, ao mesmo tempo, pelo temor ao inimigo - ou ao simples acaso que, afinal de contas, tudo comanda - e pela astuta promessa de que sempre será possível afugentá-lo tecnicamente (SIBILIA, 2012). Por isso, como nos é explicado todos os dias, os mais variados artefatos estão à nossa disposição para que possamos "controlar" com eles o confuso acontecer desta perigosa vida.

Porém, isso não é tudo. Além dessa eficácia um tanto analgésica que emana do bemsucedido "mito tecnocientificista" e sua venda parcelada de uma segurança mais ou menos garantida, agora também vivemos na "sociedade do espetáculo". Quer dizer, aquilo que Guy Debord entreviu com espanto há cinco décadas. Em plena agitação das rebeliões contra culturais, esse autor notou que estava se engendrando esta nova configuração sociocultural, política e econômica, uma de cujas definições mais citadas afirma que "O espetáculo é uma 
relação social entre pessoas mediada por imagens." (DEBORD, 2000, p. 14). Quase nada do mencionado nestas páginas teria sido imaginável no longínquo ano de 1967; no entanto, tudo isto leva a supor que algo daquela ácida previsão talvez esteja se cristalizando agora. A sua concretização envolveu alguns ingredientes imprevistos, sem dúvida, que se desenvolveram nas últimas décadas, mas é inevitável associar o que acontece hoje em dia com aquilo que Debord (2000) intuiu, com furioso desdém, numa época em que recursos técnicos como a internet nem ousavam sequer habitar os mais audazes relatos da ficção científica.

É muito peculiar a combinação que atualmente se dá entre essas duas vertentes: a incitação ao espetáculo de si mesmo, por um lado; e, por outro lado, os sonhos de controle total - de todos por todos e de cada um por si - com ajuda da tecnociência. Os conflitos que essas novidades suscitam não deixam de causar toda sorte de perplexidades. Assim, por exemplo, em plena proliferação dessas estratégias de visibilidade que todos somos intimados a colocar em jogo cotidianamente, com o propósito de projetar perfis atraentes que sejam capazes de seduzir o maior número de olhares, conquistando likes e seguidores para dar espessura à própria existência, cabe se questionar se é possível ter algum controle sobre aquilo que se difunde acerca de si mesmo.

Essa pergunta evoca os casos, cada vez mais frequentes, de fotos ou vídeos de pessoas famosas em atitudes sensuais, muitas vezes sem roupas ou praticando atos sexuais, que de repente "vazam" na rede e imediatamente se transformam em notícias de alto impacto. A comoção costuma durar uns poucos dias, mas - caso não seja capitalizada com certa fortuna - seus efeitos podem ser desastrosos. É cada vez mais comum que isto aconteça também fora do âmbito glamoroso das celebridades, como é o caso dos adolescentes que produzem esse tipo de registros audiovisuais e depois os fazem circular pelas redes, perturbando o clima escolar ou familiar ao suscitar dramas de novo cunho que ninguém está em condições de resolver.

Nessa mesma linha tem se dado à luz todo um subgênero altamente polêmico: a "pornografia de vingança", exercida por um membro de um casal separado que divulga essa classe de imagens realizadas na intimidade. Algo semelhante acontece com a prática conhecida como bullying, outra manifestação bem contemporânea que costuma desembocar em tragédias mais ou menos graves. Embora seja habitual supor que não se trata de nenhuma novidade, mas de uma atualização - e talvez até de uma generalização - do clássico assédio escolar que sempre teria existido, o fato é que tanto o fenômeno como a 
palavra para nomeá-lo são bastante recentes e estão muito afinados com a dinâmica atual (SIBILIA, 2017). Não é por acaso que hoje o constrangimento se multiplica exponencialmente graças à sua virtual exibição em inúmeras telas; como consequência dessa irradiação, pode chegar a ter efeitos descomunais. Quando se dissemina pelas redes informáticas, a humilhação decorrente de um ato vergonhoso se torna ainda mais asfixiante, pois o que antes costumava ser de ordem privada - limitando-se ao interior da escola, do lar ou do pequeno círculo íntimo - agora se joga no âmbito público com uma abrangência potencialmente infinita.

Neste contexto, as reivindicações pelo "direito ao esquecimento" parecem justíssimas. Aqui emerge, porém, outra das complicações deste assunto: como consegui-lo? Como obter esse apagamento tão buscado, quando algo indevido escapole pelas entrelinhas da própria cuidadosa curadoria existencial e estoura sem filtros? Se a espetacularização de si mesmo se legitimou e se generalizou de modo tão irrefutável, a pretensão de manter algum controle sobre os próprios dados em suporte digital torna-se cada vez menos plausível. Ainda mais quando se trata de imagens com teor erótico, essas faíscas especialmente inflamáveis que se deslizam pelas telas como um pavio de pólvora, despertando grande voracidade e desdobramentos incalculáveis. Talvez os dois componentes dessa equação - espetáculo e controle - sejam inconciliáveis, pois não constituem duas linhas paralelas, mesmo sendo tortuosamente complementares. Mas acontece que há, em seu horizonte, um brusco choque em potencial. De modo que a única forma de controlar o que se diz sobre si mesmo - incluindo aí o que cada indivíduo conta ou mostra acerca da própria vida - seja se abstendo não só de fazê-lo circular, mas também de produzir qualquer documento digital a seu respeito. E, além disso, evitar que os outros o façam.

Algo altamente improvável, aliás. E que poderia ser digno de pesadelos para boa parte dos sujeitos contemporâneos; ou seja, esses seres que se converteram em loquazes autores, narradores e personagens de si mesmos. Vale notar que essas criaturas, os personagens, nunca estão sozinhas. Sempre há alguém para testemunhar tudo o que eles fazem, alguém que segue com avidez seus atos e gestos, seus sentimentos e pensamentos, até suas emoções mais minúsculas ou banais costumam estar sob observação. Há sempre um espectador, um leitor, uma câmera, um olhar sobre o personagem que usurpa dele seu caráter meramente humano, mesmo que seja um personagem real como qualquer um de nós. Para poder existir, esse tipo de sujeito precisa fervorosamente desse olhar alheio 
apontando para a sua figura (SIBILIA, 2016). Por isso resulta tão insuportável, para as subjetividades "alterdirigidas" que tanto proliferam hoje em dia, deixar de contar com esse reconhecimento constante (RIESMAN, 1995).

Na vida corrente de qualquer mortal, porém, nem sempre há um público disposto a observar as suas ações: nem as heroicas, nem as miseráveis, e menos ainda as trivialidades cotidianas. Com demasiada frequência, aliás, ninguém nos olha, tampouco somos aplaudidos ou festejados. Nesses casos altamente habituais, não temos testemunhas do que fazemos e nem do que somos. Algo que não seria muito grave e até poderia significar um alívio, se não vivêssemos imersos numa cultura como a contemporânea. Isto é, numa sociedade na qual a verdade sobre quem se é deixou de brotar prioritariamente da interioridade psicológica, ou seja, daquele âmago que permanecia zelosamente resguardado "dentro" de cada indivíduo e que constituiria a própria essência (BEZERRA, 2002). Em vez disso, de modo crescente, cabe ao olhar alheio o poder de irradiar essa verdade, ao avaliar tudo - e tão somente - o que cada um é capaz de mostrar, seja de modo voluntário ou não.

As redes sociais da internet são canais extremamente adequados para consumar esses jogos, deixando em mãos de cada um a capacidade de comandar seu próprio relato. No entanto, mesmo dispondo de tais recursos e usando-os ativamente, se ninguém constata ou - ainda melhor - se ninguém celebra a nossa existência traduzida em valiosas imagens, como garantir que somos alguém ou que temos algum valor? Se forem poucos aqueles que nos "seguem", os que clicam no botão "curtir" ou deixam algum comentário positivo diante da última selfie que postamos na internet, então: como confirmar que existimos ou que somos valiosos? Embora os personagens às vezes pareçam estar a sós, não é o que de fato acontece: eles sempre estão à vista. Absolutamente tudo em suas vidas deve acontecer sob os olhos mais ou menos gulosos de algum espectador ou leitor, ou então dos mais atuais seguidores, amigos ou fãs. Assim como costuma ocorrer com qualquer um de nós, nestes tempos de gregarismo interconectado que nos incita a performar constantemente na visibilidade de qualquer cenário: sozinhos, não existimos. Os personagens somente são (ou estão ou existem ou supõe-se que valem) quando alguém os observa, sobretudo se esse público for amplo e ativo. Sob esse olhar tão cobiçado e tão cotidianamente quantificado, eles ganham a sua fantástica vitalidade. Aí é onde reside o núcleo deste dilema, portanto: como resistir a esse anseio atual de se mostrar e mendigar aplausos, mesmo sabendo que pode ter perigosas consequências, se o mundo nos converteu em verdadeiros personagens? 


\section{0 luxo do anonimato: sonho ou pesadelo?}

Considerando tudo o que foi exposto nos parágrafos anteriores, cabe deduzir que o anonimato não é uma possibilidade viável hoje em dia, supondo que alguém pudesse chegar a desejá-lo. Entre tantos cruzamentos de dados que integram as densas redes informáticas da atualidade, se algum excêntrico cidadão do globalizado século XXI quisesse se manter na obscuridade do invisível, provavelmente não conseguiria. 0 velho sonho da ilha deserta, por exemplo, não parece mais realizável; aliás, nem é sequer imaginável hoje em dia como pura fantasia. Pelo menos, não sem wi-fi; e, portanto, com acesso aos apetecidos - mas também bastante temíveis - portais de Google ou Facebook.

Este parece ser o ponto culminante daquilo que Walter Benjamin compreendera, em seus escritos da década de 1930, como o "triunfo sobre o anonimato". Acompanhando o percurso de seu famoso flâneur pelas ruas de Paris, o ensaísta alemão descreveu alguns mecanismos de controle administrativo arduamente implantados na Europa do século XIX, como os processos de identificação dos cidadãos e o reordenamento urbano das populações. Todos fatores imprescindíveis para a modernização do mundo então em andamento. Naqueles textos, entretanto, o autor constatava algo fundamental para o projeto moderno: “[...] um homem se torna mais suspeito quanto mais difícil seja encontrá-lo." (BENJAMIN, 1985, p. 76).

Com a transição do paradigma analógico para o digital, as tecnologias de processamento de dados reduziram ainda mais as possibilidades de permanecer oculto, alheio ao controle, fora da abrangência das tentaculares redes (SIBILIA, 2015). Não apenas porque não é mais possível se esconder, mas, sobretudo, porque quase ninguém deseja fazêlo. Por isso, as novas ferramentas informáticas parecem concluir o processo iniciado pelas técnicas criminalísticas da época comentada por Benjamin (1985), como a assinatura, a carteira de identidade e a fotografia. "A história de detetives surge no instante em que se assegura essa conquista, a mais decisiva de todas, sobre o anonimato do homem [...]", afirmava então o filósofo; "[...] a partir daí, não se pode mais pressentir onde acabarão os esforços para fixá-lo no falar e no fazer." (BENJAMIN, 1985, p. 76).

Contudo, o ponto mais extremo dessa trajetória talvez não tenha sido aquele vislumbrado já faz quase um século no célebre texto de Benjamin. Essa culminação pode ser intuída, de modo muito mais crucial, na exposição por livre vontade que se consumou nos últimos anos através de canais interativos como as redes sociais da internet ou os 
aplicativos para celulares, que permitem manter um circuito de contatos permanentemente ativado e sempre alerta. Através desses dispositivos, todos os dias, milhões de indivíduos comunicam dados de toda classe sobre si mesmos, inclusive textos e imagens pessoais de diversa índole. Entre essas últimas se destacam, cada vez mais, as fotografias e os vídeos que expõem a própria nudez. Muitos investem nessa tarefa de auto exibição boa parte de sua energia e seu tempo, mas não se trata só disso: todos eles costumam monitorar também, com diversos graus de curiosidade e afinco, as informações relativas a quantidades crescentes de gente interconectada e facilmente localizável.

A maioria desses usuários adota tais práticas com prazer e bastante entusiasmo, cumprindo rituais de cotidiana devoção por livre vontade, e não porque alguma autoridade os obrigue a fazê-lo como um sofrimento imposto sob o peso da lei. Pelo menos, isso é o que costuma acontecer até a situação ficar complicada e terminar revelando, de repente, a sua face mais obscura. Se isso ocorrer, a tecla delete será abraçada como uma ambígua promessa de salvação absoluta. É então quando o "direito ao esquecimento" aparece como uma válvula legal que procura cumprir, de algum modo, essa virtual impossibilidade. Por isso, alguns autores que se debruçaram sobre o assunto, como é o caso de Viktor MayerSchonberger, autor do livro Delete: The Virtue of Forgetting in the Digital Age (2011), propõem soluções alternativas, tais como "[...] uma data de expiração para a informação, para nos confrontarmos com a finitude da memória e nos ajudar a compreender (e apreciar) que a informação tem um tempo de vida limitado." (MAYER-SCHONBERGER, 2011, p. 15, tradução nossa). De fato, essa demanda pelo efêmero dos dados online foi, de algum modo, explicitada no sucesso mais recente de aplicativos como Snapchat ou Instagram Stories.

Entretanto, essa tentativa de driblar o problema não parece ter sido suficiente. Google continua sendo um poderoso emblema desse conflito: o buscador mais usado da internet constitui não apenas uma sorte de oráculo que tudo sabe, mas também uma instância legítima - ou, pelo menos, assim legitimada, inclusive pelas instituições jurídicas mais respeitadas e poderosas do mundo - para administrar as referências pessoais de seus milhões de usuários de todo o planeta. Afinal, que dúvida pode restar: "você é o que Google diz que você é", conforme afirmava o advogado citado no início deste ensaio. Por isso mesmo, tentar lhe colocar barreiras jurídicas - ou de qualquer outro tipo - pode resultar tão inócuo como problemático ou até mesmo paradoxal.

O debate continua e está longe de ter cicatrizado. No entanto, esta polêmica em torno do "direito ao esquecimento" na internet já parece indicar algo importante. Talvez seja 
mais um indício de uma mudança histórica de enorme magnitude e complexidade, que vem se anunciando há algum tempo e cujos sintomas se vislumbram por toda parte. Em suma, sublinhando algo que já foi insinuado nestas páginas, mas ora reformulado a partir desta nova perspectiva e a modo de conclusão, cabe ressaltar que a verdade tem deixado de emanar do interior de cada um, como costumávamos pensar até pouco tempo atrás. Agora ela brota do olhar alheio. Esse trânsito de um modo moderno de entender a memória, para uma forma contemporânea e ainda em coagulação, parece se confirmar cada vez com mais força, inclusive no que se refere a algo fundamental: quem se é, quem se tem sido e quem se poderia chegar a ser.

\section{Referências}

BENJAMIN, Walter. A Paris do Segundo Império em Baudelaire. In: BENJAMIN, Walter. Sociologia. São Paulo: Ática, 1985.

BERGSON, Henri. Matéria e memória. São Paulo: Martins Fontes, 1999.

BEZERRA, Benilton. 0 ocaso da interioridade e suas repercussões sobre a clínica. In: PLASTINO, Carlos (Org.). Transgressões. Rio de Janeiro: Contra Capa, 2002.

BORGES, Jorge Luis. El Aleph. In: BORGES, Jorge Luis. Obras completas. Buenos Aires: Emecé, 1999a. v. 1, p. 617-627.

BORGES, Jorge Luis. Funes el memorioso. In: BORGES, Jorge Luis. Obras completas. Buenos Aires: Emecé, 1999b. v. 1, p. 485-490.

BRILHO eterno de uma mente sem lembranças. Direção: Michel Gondry. Produção: Anthony Bregman e Steve Golin. [S.l.]: Focus Features; Universal Pictures, 2004.

DEBORD, Guy. A sociedade do espetáculo. Rio de Janeiro: Contraponto, 2000.

DELEUZE, Gilles. Post-scriptum sobre as sociedades de controle. In: DELEUZE, Gilles.

Conversações: 1972-1990. Rio de Janeiro: Ed. 34, 1992.

FOUCAULT, Michel. Vigiar e punir. Petrópolis: Vozes, 1977.

FREUD, Sigmund. Obras completas. Buenos Aires: Amorrortu, 1978.

GIANBARTOLOMEI, Mauricio. Hostigamiento anónimo: cuando un extraño te arruina la vida. La Nación, Buenos Aires, 15 out. 2012. Disponível em: <http://www.lanacion.com.ar/1516028-hostigamiento-anonimo-cuando-un-extrano-tearruina-la-vida>. Acesso em: 10 mar. 2018.

MAYER-SCHONBERGER, Viktor. Delete: the virtue of forgetting in the digital age. Princeton: Princeton University Press, 2011. 
NIETZSCHE, Friedrich. Segunda consideração intempestiva: da utilidade e desvantagem da história para a vida. Rio de Janeiro: Relume Dumará, 2003.

RIESMAN, David. A multidão solitária. São Paulo: Perspectiva, 1995.

SIBILIA, Paula. A técnica contra o acaso: os corpos inter-hiper-ativos da contemporaneidade. In: FERRAZ, Maria Cristina Franco; BARON, Lia (Org.). Potências e práticas do acaso: o acaso na filosofia, na cultura e nas artes ocidentais. Rio de Janeiro: Garamond: FAPERJ, 2012. p. 177-192.

SIBILIA, Paula. 0 homem pós-orgânico: a alquimia dos corpos e das almas à luz das tecnologias digitais. Rio de Janeiro: Contraponto, 2015.

SIBILIA, Paula. Bullying: La vergüenza. Anfibia: revista de la UNSAM, Buenos Aires, 5 ago. 2017.

SIBILIA, Paula. 0 show do eu: a intimidade como espetáculo. Rio de Janeiro: Contraponto, 2016.

\title{
You are what Google says you are: the editable life, between control and spectacle
}

\begin{abstract}
This article resumes the debate on the "right to oblivion" that some Internet users are demanding to search engines such as Google and Yahoo. In such cases, people ask to erase certain personal data related to past situations which, even if these are true, the applicant considers that somehow harm their own reputation. Discussions on this issue seem to suggest that some important changes are taking place, regarding the ways in which we relate to our reminiscences. This fact could be opening the moral and legal horizon towards an "editable memory" whose criterion of truth resides in the exposure to the others' gaze. It is an essayist reflection that proposes a genealogical perspective, in dialogue with fundamental authors of the nineteenth and twentieth centuries, such as Benjamin, Bergson, Borges, Debord, Deleuze, Foucault, Freud and Nietzsche.
\end{abstract}

\section{Keywords}

Memory. Oblivion. Internet. Subjectivity. Visibility.

Recebido em 20/07/2017

Aceito em 07/11/2017 